\title{
The Principles of Traditional Knowledge Protection in the Perspective of Indonesian National Law
}

\author{
Andy Usmina Wijaya ${ }^{1} \quad$ Endang Prasetyawati ${ }^{2}$ \\ 1.Doctor Candidate of Legal studies of Law Faculty of Universitas 17 Agustus 1945 \\ 2.A lecturer of Law Faculty of Universitas 17 Agustus 1945
}

\begin{abstract}
Indonesia is rich in culture, both historical heritage and traditional knowledge with enormous potential to produce various kinds of works and traditions from all regions of Indonesia. However, indigenous people as the owners of traditional knowledge do not have much protection when foreign parties exploit the cultures without permission to acknowledge the culture as their property. So far, the intellectual property regime has not been able to protect because of the different protection concept. The state of Indonesia also does not have specific laws and regulations yet to protect the traditional knowledge of those indigenous people. This dissertation research uses statute approach, conceptual approach, comparative approach, and philosophical approach.The result of this research shows the concept of traditional knowledge is part of the intellectual property rights regime, whether it is owned, controlled, or used by a particular community or ethnic group which is hereditary and it continues to develop linear to the environmental changes. The ownership of traditional knowledge is a collective communal. It is different from other intellectual property rights regimes which are more individualistic. The legal protection that can be applied to traditional knowledge is based on the recognition and protection of human dignity, which is originated from Pancasila and the rule of law of preventive and repressive legal protection
\end{abstract}

Keywords: traditional knowledge, intellectual property rights, legal protection

DOI: $10.7176 / \mathrm{JLPG} / 103-03$

Publication date: November $30^{\text {th }} 2020$

\section{BACKGROUND}

As a country with extraordinary cultures and resources diversity, Indonesia has an enormous economic potential to support a sustainable economic development process. It is not surprising that this value has caused foreigners to repeatedly exploit without permission nor recognize the Traditional Knowledge as their own. This is happening because Indonesia still does not have laws and regulations to protect the traditional knowledge of indigenous people until now. In legal terms, this situation is called a legal vacuum for protection regulation of traditional knowledge in Indonesia.

The absence of traditional knowledge recognition as part of intellectual property rights (IPR) caused no legal protection to misappropriation committed by foreigners, including in Indonesia. This occurs because of the differences of the unique characteristics related to the collective communal of traditional knowledge and the private rights of IPR regime in general. Basically, the essence of the legal protection of traditional knowledge in Indonesia started from IPR regime.

Based on the background above, the problem statement which can be elaborated is the regulation of traditional knowledge protection in the perspective of Indonesian national law.

\section{RESEARCH METHODOLOGY}

This type of research is normative juridical, which uses primary and secondary legal materials. Normative juridical research emphasizes the distinctive character of the legal study of positive law, including 3 (three) surfaces of legal study, i.e legal dogmatic, legal theory, and legal philosophy.

This research uses statute approach, conceptual approach, comparative approach, and philosophical approach.

\section{DISCUSSION}

\subsection{Intellectual Property Rights in General}

IPR comes as the result of creative activities, the ability of human's thinking which is expressed to the general public in various forms, such as technology, science, art, and literature, which has benefits and economic value, and also are useful for life. As property rights which occur formwork, initiative, or creation, human intellectual abilities can be recognized. In other words, those who create or make, have control for benefit purposes. IPR regimes that have been recognized are Copyright, Neighboring Rights, Trademarks, Patents, Trade Secrets, Geographical Indications, Industrial Designs, Layout Designs of Integrated Circuits, and Plant Variety Protection. 


\subsection{Traditional Knowledge As Part of Intellectual Property Rights}

Traditional knowledge including health, spirituality, culture, and language cannot be separated from the indigenous people who have them, because traditional knowledge is a way of life. Therefore, it can be said that traditional knowledge was born from the survival of indigenous people. Traditional knowledge initially involved the process of creating materials provided by nature to be transformed into something useful for the lives of indigenous people. It is also defined as a knowledge which is owned, controlled, and used by a particular community or ethnic group. It is hereditary and it continues to develop linear to the environmental changes.

CBD Article 8 letter $\mathrm{J}$ regulates traditional knowledge that based on its national legislation, each country which is the signatory of the Convention should respect, protect, and defend the knowledge, innovations, and practices of the indigenous and local community to reflect a characteristic of traditional lifestyles, under the conservation and sustainable use of biological diversity. Those countries also must advance wider application with the consent and involvement of traditional knowledge owners. It will raise equitable benefit sharing from the efficient use of those knowledge, innovations, and practices. CBD regulation of traditional knowledge is connected to TRIPs agreement. TRIPs Article 27 paragraph 3 of biological diversity stated that the Member States can also regulate exemptions from patent protection for 1) plants and animals, except micro-organism, and 2) biological processes that are important for the production of plant and animal, except non-biological and microbiological processes.

\subsection{The Importance of Traditional Knowledge Recognition}

Although traditional knowledge is human's intellectual work, it does not mean that the concept is linear with conventional intellectual property such as copyrights, trademarks, and patents. The concept of property right has economic value and it is part of material rights. IPR does not protect thoughts or ideas, but the result of those thoughts and ideas expressed. Therefore, IPR only protects the economic interests of the results of thoughts, not the material form, such as medicines, herbs, books, songs, pictures and others, neither the idea, such as knowledge of making medicine, knowledge of writing, knowledge of composing, or knowledge of creating songs. In other words, intellectual property has economic interests from thoughts or ideas, and not objects (goods or rights).

The refusal of the social collective rights recognition by developed countries is basically the desire to dominate developing countries with the forms of protection for traditional knowledge. To protect the rights of communalistic indigenous people, developed countries impose individualistic Western concepts.

\subsection{Legal Protection Principles for the People}

The principle of recognition and protection of human rights in the Republic of Indonesia does not require individualistic inclusion. The central point of Indonesia is the harmony between the government and the people based on harmonization principle. From this principle, other elements of Pancasila concept are developed, i.e the establishment of a proportional function relationship between state power, deliberative settlement of disputes, and settlement through the judiciary. Human rights do not only emphasize rights and obligations but the balance between rights and obligations. The form of legal protection for the people of the government is directed to (a) efforts to prevent or reduce disputes, (b) efforts to resolve legal disputes between the government and the people through deliberation, (c) Dispute resolvement through judiciary is the last effort to reach an agreement.

\subsection{The Meaning of Traditional Knowledge Ownership in Indonesia}

If the existence of objects of traditional knowledge protection is being connected to the result of indigenous people, the criteria expressed above have shown that the traditional knowledge object is based on common property. Therefore, the groups or parties in the area mentioned have a major role to protect the potential product of indigenous people.

As part of intellectual property, the general principles of law property certainly applied to traditional knowledge regime as well as other IPR regimes. However, the unique characteristics of traditional knowledge with collective communal ownership have given different nuances in the application of IPR principles as they should be. The concept of collective communal ownership originates from the existence of a community unit which has the same belongings and interests.

The concept of collective communal refers to the rights that can be enjoyed by many people or groups. Meanwhile, related to traditional knowledge as part of common property, this concept can be interpreted that the community has the same opportunity to enjoy the potential products of traditional knowledge. On customary law perspective, traditional knowledge ownership is inherent to collective communal. These certain characteristics show the need for the development of IPR principles.

The formation of social institutions is a crystallization of methods, habits, and customs when the distribution and implementation of traditional knowledge are performed from generation to generation. The institutionalization of traditional knowledge will build collective awareness of the community to establish a 
reciprocal relationship to maintain their traditional knowledge. This reciprocal relationship often points out indigenous people as the holders of traditional knowledge rights. Interested parties and the State (Government) as the rulers cannot be separated from the concept of communal collective ownership concept of traditional knowledge. The term of interested parties is used in the TRIPs regulation as parties who have the authority to protect traditional knowledge. It means interested parties can take preventive action against the use of traditional knowledge that is not linear with the actual condition, including unfair competition business. These parties are connected with the characteristics of traditional knowledge as the part of IPR regime.

The concept of interested parties refers to the subject of rights holders, which implicitly shows that traditional knowledge has been recognized as having different characteristics from other IPR regimes that are inherent to communal collective ownership. Interested parties can be interpreted as institutional. The traditional knowledge protection system is provided to the parties or institution who are entitled as the rights holders if there is a registration form submitted by the applicant to the competent authority.

\subsection{Traditional Knowledge Regulation in Several Countries}

One of the traditional knowledge protection regulation performed by several countries in the world is Model Law. It is formulated by developing countries which refers to the concept of the collective right. It arises from traditional societies, but it is not collective rights that developed from western collectivism. The country that applies this concept in Tunisia. Ghana protects its traditional knowledge using the Copyright regime. Traditional knowledge is the folklore category. The different concept of traditional knowledge protection regulation is shown by Australia which tries to use the Customary Laws of Aboriginal communities combined with the modern IPR regime. Customary law is applied to determine the rights holders of traditional knowledge, and the protection uses copyright IPR regime. New Zealand protects its traditional knowledge using prior informed consent $(P I C)$.

\subsection{The Model of Traditional Knowledge Regulation in Indonesia}

Regarding the IPR protection, Pancasila at philosophical level contains the fundamental basic values that must cover the laws under it. At the level of norms, Pancasila has implementation values. While in the context of legal interpretation of legal discovery by judges on certain cases, Pancasila contains social practical values as a characteristic which is different from other justice values. Social justice aims to achieve a just and prosperous society spiritually and materially to the public welfare. Social justice can be fulfilled if all citizens are obliged to act and behave fairly because it can only be achieved if each individual acts and develops a fair attitude towards others.

Legal studies have shown that until now Indonesia does not have its traditional knowledge regulation. The fact of traditional knowledge misappropriation in Indonesia, it is necessary to present specific laws as long-term references to traditional knowledge protection policies. Regulation is one of the tools to protect indigenous people's right from misappropriation by other parties. Indonesia can consider the specific regulation or sui generis of traditional knowledge. The sui generis system is necessary, considering that the current IPR regime is not suitable to protect traditional knowledge from misappropriation, especially by foreign parties.

The importance of sui generis regulation is a firm acknowledgement that indigenous people as the owners or rights holders of traditional knowledge. The application of customary law can be an alternative source (material) in formulating the indigenous people's rights in sui generis. The customary law principles that can be used in sui generis law are first, sui generis regulation is simple. Second, sui generis is expected to not ignore religious norms. Third, sui generis is based on the social system which upholds and appreciates values of togetherness and not being individualistic. Fourth, sui generis must be able to ensure that the implementation of the use of traditional knowledge can provide welfare for a large community.

\section{Conclusion}

1. The principal of traditional knowledge as knowledge that is owned or occupied and used by a particular community, community or ethnic group which is inherited and maintains to develop in accordance with environmental changes as part of the IPR regime needs legal protection in Indonesia. The significance of traditional knowledge for legal protection is due to the practice of misappropriation of traditional knowledge and the strong will to occupy and dominate developing countries in relation to the proposed form of protection for traditional knowledge by developed countries. The economic aspect of consuming traditional knowledge will drive sustainable growth in the regions and become the capital for Indonesia's development. This utilization can be completed, among others, by empowering the potential of each of these various regions by involving the participation of indigenous people.

2. The ownership of a traditional knowledge is very dissimilar from other IPR regimes which are more distinctive. For traditional knowledge, the ownership is collective communal owned by the indigenous people who own the traditional knowledge. Basically, the utilisation of traditional knowledge can be carried 
out together by interested parties, so that ownership of common property is inherent in the nature of collective communal rights. The legal protection that can be employed to traditional knowledge arises from the recognition and protection of human dignity and originates from Pancasila and the principles of the rule of law with means of protection including preventive and repressive legal protection.

\section{References}

Imam Sudiyat, Hukum Adat, Sketsa Asas, Liberty, Yogyakarta, 1981

Locke J, Two Treatise of Goverment: Chapter V of Property, London: C Baldwin, 1824, Havard University, Library.

Lili Rasjidi dan I.B. Wyasa Putra. Hukum sebagai suatu Sistem, CV Mandar Maju, Bandung, 2003

Mochtar Kusumaatmadja. Hukum, Masyarakat dan Pembinaan Hukum Nasional: Suatu Uraian tentang Landasan Pokok Pikiran, Pola dan Mekanisme Pembaharuan Hukum di Indonesia, Bandung, Lembaga Penelitian Hukum dan Kriminologi FH Unpad, 1976.

Philipus M. Hadjon, Perlindungan Rakyat Bagi Rakyat di Indonesia (sebuah Studi tentang Prinsip-Prinsipnya, Penanganannya oleh Pengadilan dalam Lingkungan Peradilan Umum dan Pembentukan Peradilan Administrasi Negara), PT. Bina Ilmu, Surabaya,1987.

Peter Mahmud Marjuki, Pengantar Ilmu Hukum, Kencana Pranada, Jakarta, 2008

Rahmi Jened, Interface Hukum Kekayaan Intelektual dan Hukum Persaingan, Rajagrafindo Rajawali Press, Jakarta, 2013

Soepomo, Bab-Bab Tentang Hukum Adat, Cet. 16, Pradnya Paramita, Jakarta, 2003

Sudikno Mertokusumo, Mengenal Hukum Suatu Pengantar, Cet. Ke-2, Liberty, Yogyakarta, 1999

Yudi Latif, Negara Paripurna Historis, Rasionalitas, dan Aktualitas Pancasila, Gramedia Pustaka Utama, Jakarta, 2012 